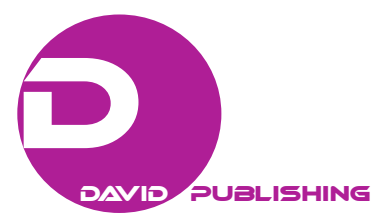

\title{
The Effects of Oil Price Volatility on Some Macroeconomic Variables in Nigeria: Application of Garch and Var Models
}

\author{
Ochoche Abraham \\ Department of Statistics, Central Bank of Nigeria
}

\begin{abstract}
The price of Nigeria's premium crude, the Bonny light has declined by about 51.8 percent between September 2014 and January 2015. Given that this resource is the major source of revenue for Nigeria, the possible effects on the economy of these continuing shocks in oil prices are definitely of prime interest in order to predict the effects of a drastic change in oil prices, on the Nigerian economy as a whole. This study investigates the impact of oil price shocks on the Nigerian economy using quarterly time series data from 1985Q2-2014Q3. The study employed GARCH model and a multivariate VAR analysis using impulse response functions and variance decompositions tests to examine the interrelationship among the variables. The impulse response functions show that oil price shocks have immediate and prolonged effect on all the macroeconomic variables considered. Thus, we conclude that oil price shocks have a direct impact on real GDP, total monetary assets and credit to private sector and as such urgent and serious efforts should be made to cut back on government expenditure, increase the tax base, diversify the economy and improve the overall efficiency and scope of other existing non-oil revenue sources, so as to ameliorate the impact of falling oil prices.
\end{abstract}

Keywords: Oil price volatility, Oil price, GARCH, VAR, Impulse response, Variance decomposition

\section{Introduction}

Oil price volatility is a measure that intends to capture the risk faced by the Nigerian economy due to unpredictable fluctuations in the price of crude oil. The study used a measure derived from Brooks (2014) generalized autoregressive conditional heteroscedasticity $(\mathrm{GARCH})$ models.

Nigeria is popularly known for crude oil which is her dominant source of revenue. Nigeria's proven oil reserves are estimated to be 35 billion barrels; natural gas reserves are well over 100 trillion $\mathrm{fti}(2,800 \mathrm{kmi})$ (Odularu, 2008). Petroleum accounts for up to 80 percent of all government revenue (government revenue was an estimated \$20.7 billion in 2014) and more than 90 percent of the country’s exports (Campbell, 2014). From figure 2 it is clear from the very strong similarity of their curves that federally collected revenue (FC_Rev) is almost totally dependent on oil price from 1998 -2013,. Nigeria became increasingly dependent on oil revenue as the main stay of the Nigerian economy, and given the propensity of shocks in oil price in the past few decades and more importantly in recent months, the possible effects on the economy of these shocks in oil prices are definitely of prime interest to economists in order to predict the effects of a drastic change-increase

Ochoche Abraham, Ph.D., Statistics Department, Central Bank of Nigeria, PMB 0187, Abuja, Nigeria. E-mail: oabraham@cbn.gov.ng.

The views and conclusions drawn herein are purely that of the Author and should not be seen as representing the position of the Central Bank of Nigeria. 
or decrease in oil price, on the Nigerian economy as a whole. Oil shock or volatility can be described as a sudden, unexpected change in oil price or production. This study, however, focuses on the effect of oil price shocks on macroeconomic and monetary variables in Nigeria.

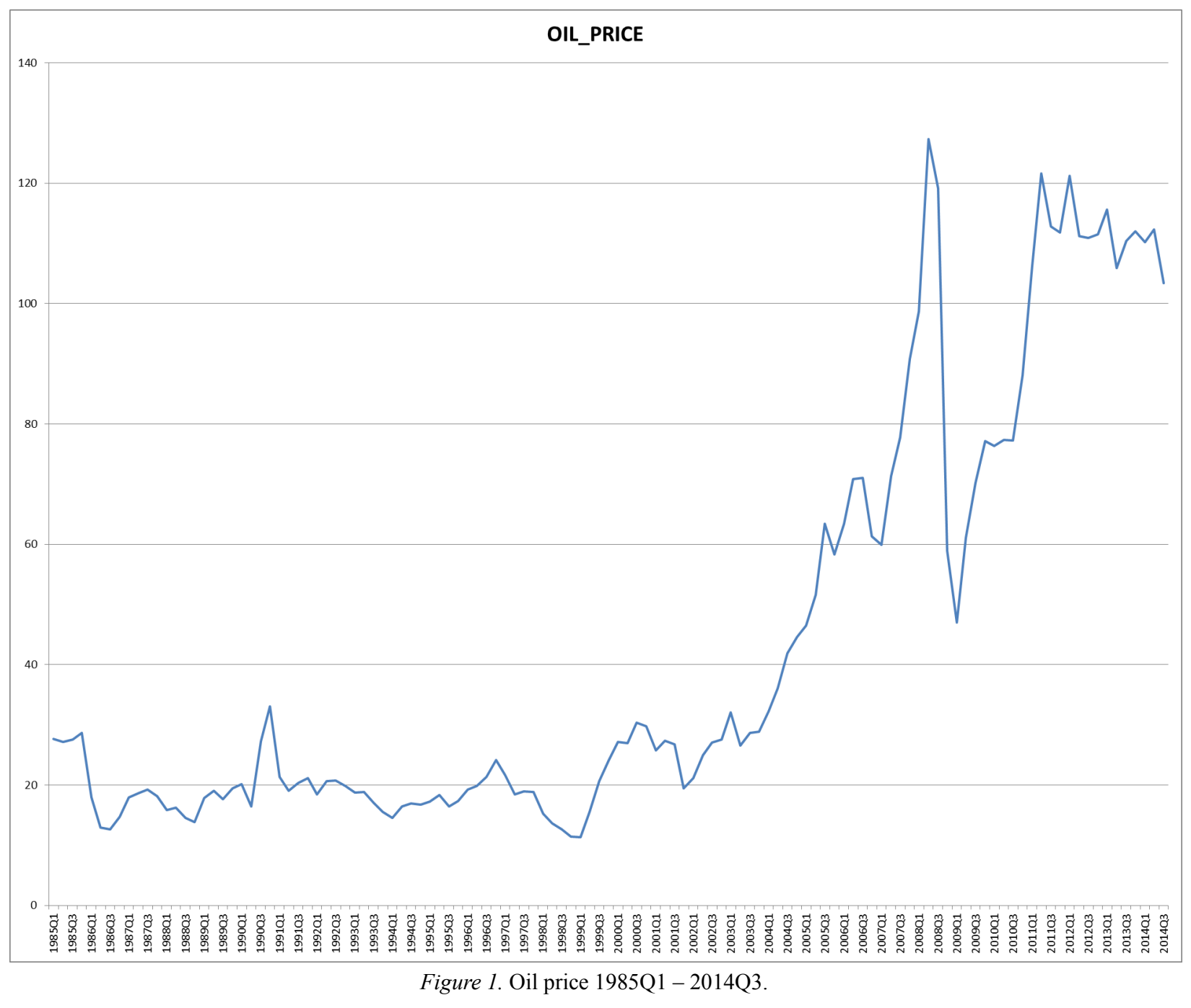

In 1961, a total export in Nigeria was dominated by cocoa, groundnut and rubber, in that order crude oil accounted for a paltry 7.1 per cent of total exports. In 1965, contributions of oil had climbed to 13.5 per cent of the nation's export earnings, and by 1970, it had become the leading source of foreign exchange, accounting for about 63.9 per cent of total earnings. Following the 1973 Arab oil embargo against the United States of America Nigeria experienced a windfall in revenue and oil boom. By 1979, petroleum sales had completely overshadowed non-oil exports, as it then contributed about 95 per cent of the country's export earnings (Petters, 2000).

Evidences from past decade show that oil price per barrel rose from US\$4.81 in 2001 to US\$74.96 in 2007 and an outrageous US\$138.74 in mid-2008, declining sharply to US\$46.64 by January 2015. Nigeria's premium crude, the Bonny light continued to trade at over $\$ 100$ per barrel up to early September 2014 and then the drop began and has persisted reaching a low of $\$ 46.64$ in January 2015 . Persistent oil shocks such as this 
could have extensive effects on the macro economy, thus inducing challenge for policy making - fiscal or monetary in both oil exporting and oil importing countries.

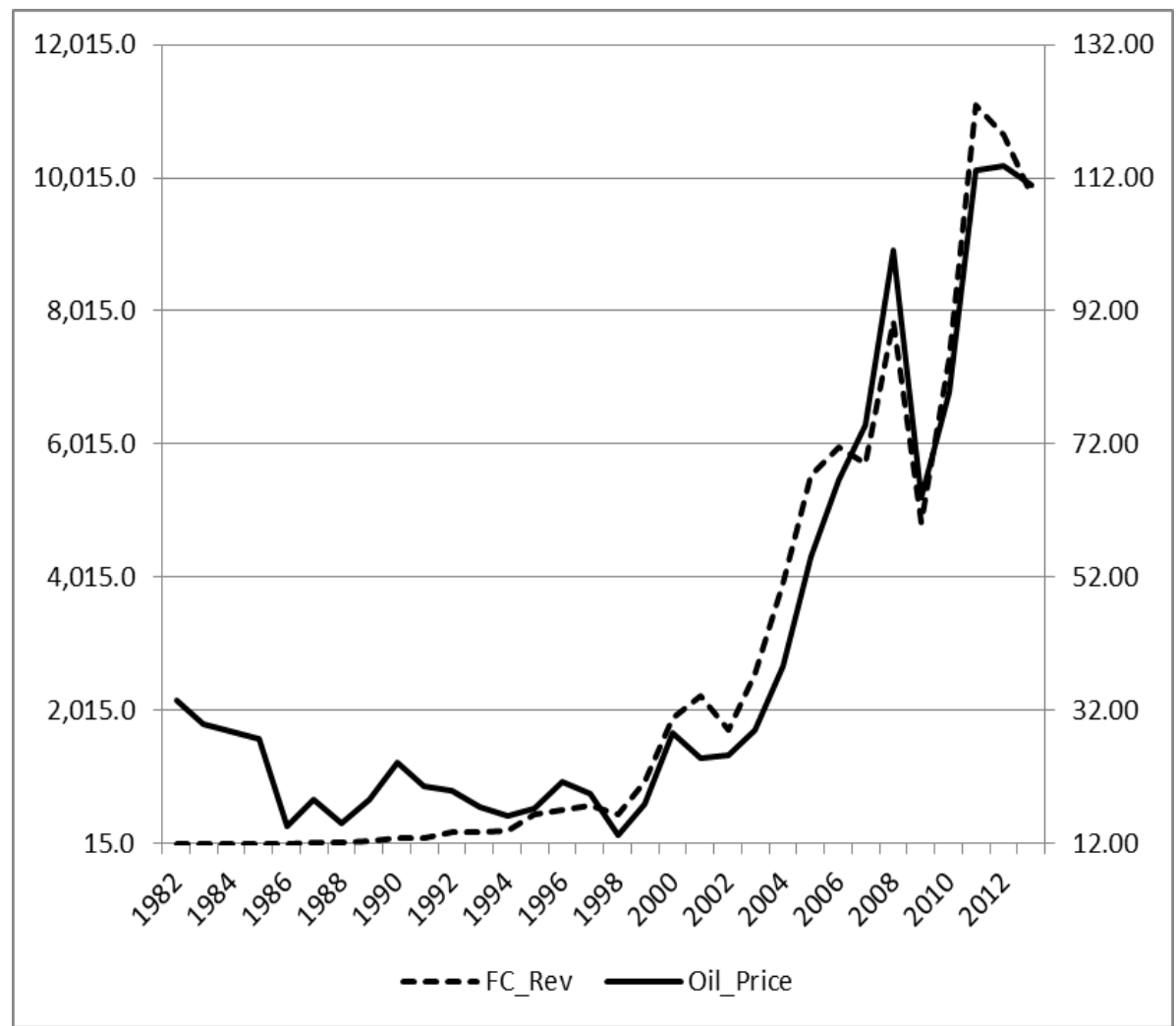

Figure 2. Oil price and Federally collected revenue 1982 - 2013.

\section{Review of Theoretical Literature}

Ogundipe and Ogundipe (2008), carried out a study that estimated the impact and transmission channels of oil price shocks on investment and how it affects the Nigerian economy. They made use of annual data from 1970-2011. Their study employed a multivariate VAR analysis using impulse response functions, variance decompositions and Granger Causality tests to examine the interrelationship among the variables. They found evidence that supports a unidirectional causality running from domestic investment to stabilize oil prices. Also, from Granger Causality tests they discovered a bidirectional relationship between oil prices and savings. They also discovered from the impulse response functions that oil price shocks have little effect on Real GDP. They then concluded that oil price shocks do not have a direct impact on Real GDP, but it can influence other variables that significantly influence Real GDP like investment and savings.

Mordi and Adebiyi (2010), developed a structural VAR model and used it to analyze, in a unifying model the asymmetric impact of oil shocks on output and price is. They applied the model to Nigeria using monthly data spanning 1999:01 to 2008:12 and the empirical results show that the impact of oil price shocks on output and prices is asymmetric in nature; with the impact of oil price decrease significantly greater than oil price increase. Also, from the variance decompositions, they concluded that oil price changes play a significant role in determining the variance decompositions of output and prices.

Umar and Abdulhakeem (2010), examined the impact of oil price volatility on four key macroeconomic 
variables in Nigeria namely real GDP, money supply, unemployment and consumer price index by using vector auto regression model. They discovered that oil prices had a significant impact on real GDP, money supply and unemployment but an insignificant impact on consumer price index is not significant. They then concluded that the economy is vulnerable to external shocks and recommended the diversification of the economy..

Asaolu and Ilo (2012), carried out an investigative study to ascertain the relationship between the Nigerian stock market return and crude oil price by employing the cointegration and vector error correction (VECM) framework using time series data from 1984 to 2007. They discovered the existence of a long-run relationship between Nigerian stock market return and oil price. They also discovered that Nigeria is susceptible to the "oil up, stock down" rule, which was quite a surprise, given that Nigeria is a major oil exporting country. The explained this anomaly by pointing to the country's failure to translate its huge foreign exchange earnings from oil into an improved industrial sector productivity

\section{Method}

\section{Research Model}

\section{Generalized Autoregressive Conditionally Heteroscedastic (GARCH) Models.}

The GARCH model was developed independently by Bollerslev (1986) and Taylor (1986). They are specifically designed to model and forecast conditional variances. The variance of the dependent variable is modeled as a function of past values of the dependent variable and independent, or exogenous variables. A

GARCH $(1,1)$ model is given as

$$
\sigma_{t}^{2}=\alpha_{0}+\alpha_{1} u_{t-1}^{2}+\beta \sigma_{t-1}^{2}
$$

The term on the left hand side is the conditional variance because it is a one-period ahead estimate for the variance calculated based on any past information thought relevant.

An ARCH model is a special case of a GARCH specification in which there are no lagged forecast variances in the conditional variance equation; i.e., a $\operatorname{GARCH}(1,0)$.

This specification is often interpreted in a financial context, where an agent or trader predicts this period's variance by forming a weighted average of a long term average (the constant), the forecasted variance from last period (the GARCH term: $\beta \sigma_{t-1}^{2}$ ), and information about volatility observed in the previous period (the ARCH term: $\left.\alpha_{1} u_{t-1}^{2}\right)$. If the asset return was unexpectedly large in either the upward or the downward direction, then the trader will increase the estimate of the variance for the next period. This model is also consistent with the volatility clustering.

\section{Sample}

The variables considered for this study are real GDP, credit to private sector, total monetary assets (M2) and oil price specifically the growth rate of each variable was used. Tis study made use of the quarterly time series data from 1985Q2-2014Q3.

\section{Data Collection}

All data was sourced from the CBN Statistical Bulletin of 2014 as well as the Statistics Department's Statistical Database.

\section{Data Analysis and Discussion}

As explained in Ogundipe and Ogundipe (2008), the mean and median are measures of central tendency and they indicate the average value of the sample. The standard deviation of a data set, is a measure of 
dispersion, that is, it shows the extent of the deviation from the mean. It is the positive square root of its variance. On the other hand, skewness, kurtosis and probability of Jarque-Bera statistics give an indication of the normality of the distribution. Preliminary analysis of the data was carried out to determine their normality. A distribution is said to be normal when skewness is approximately zero and kurtosis is three. Also the probability of the Jarque-Bera statistics tells whether the distribution is normal or not. The null hypothesis $\left(\mathrm{H}_{0}\right)$ of the Jarque-Bera test says that the distribution is normal. Therefore if the probability value is statistically significant, we reject the null hypothesis and conclude that the distribution is not normal. In this study, a 5\% rejection region is employed and this should be sufficient as our data set is not very large (Brooks, 2014).

As can be discerned from table 1 using skewness, kurtosis and the probability of the Jarque-Bera statistics, the variables are not normally distributed. The fact that oil prices, monetary asset, GDP and credit to private sector are all highly susceptible to shocks could explain why the distribution is not normal. This can even be inferred from the minimum and maximum values of the data.

Table 1

Descriptive Statistics

\begin{tabular}{|l|r|r|r|r|}
\hline & CPSR & \multicolumn{1}{|c|}{ GDPR } & M2R & \multicolumn{1}{|c|}{ OPR } \\
\hline Mean & 6.7318640 & 1.6277970 & 5.9554240 & 2.2749150 \\
\hline Median & 5.0600000 & -3.0100000 & 5.0250000 & 2.0850000 \\
\hline Maximum & 56.4400000 & 34.7100000 & 37.6700000 & 65.8300000 \\
\hline Minimum & -38.3900000 & -10.1200000 & -8.1200000 & -50.5600000 \\
\hline Std. Dev. & 9.6781310 & 11.6342000 & 6.9995930 & 15.0467700 \\
\hline Skewness & 1.1647280 & 1.2503480 & 0.9449010 & 0.1514040 \\
\hline Kurtosis & 13.2175500 & 3.4891190 & 5.6045200 & 6.1536930 \\
\hline Jarque-Bera & 539.9714000 & 31.9225100 & 50.9114700 & 49.3509000 \\
\hline Probability & 0.000 & 0.000 & 0.000 & 0.000 \\
\hline Sum & 794.36 & 192.08 & 702.74 & 268.44 \\
\hline Sum Sq. Dev. & 10958.95 & 15836.5 & 5732.334 & 26489.42 \\
\hline Observations & 118 & 118 & 118 & 118 \\
\hline
\end{tabular}

VAR models require all variables to be stationary, therefore the stationarity all variables was tested using augmented Dickey-Fuller (ADF) test. According to the significance level at 0.05, as a first step, all variables stationarity was tested for their levels and then all variables stationarity was tested after taking the first differences. As a result, "cpsr" variable was found to be stationary at level i.e. I(0), so also was "gdpr", "m2r" while "opv" variable was found to be stationary at first difference i.e. I(I) (see Table 2).

Table 2

ADF Unit Root Test

\begin{tabular}{|l|r|r|r|r|r|c|}
\cline { 2 - 7 } \multicolumn{1}{l|}{} & \multicolumn{3}{|c|}{ Test Critical Values } & & \\
\hline Variable & $\mathbf{1 \%}$ level & $\mathbf{5 \%}$ level & $\mathbf{1 0 \%}$ level & t-statistics & Probability & Stationarity \\
\hline Credit to Private Sector (cpsr) & -4.03837 & -3.448681 & -3.14952 & -10.33784 & 0.0000 & $\mathrm{I}(0)$ \\
\hline GDP rate & -4.04053 & -3.449716 & -3.15013 & -5.689061 & 0.0000 & $\mathrm{I}(0)$ \\
\hline Total Monetary Asset (m2r) & -4.03837 & -3.448681 & -3.14952 & -11.35036 & 0.0000 & $\mathrm{I}(0)$ \\
\hline Oil price volatility (opv) & -4.0398 & -3.449365 & -3.14992 & -10.46947 & 0.0000 & $\mathrm{I}(\mathrm{I})$ \\
\hline
\end{tabular}


The Effects of Oil Price Volatility on Some Macroeconomic Variables in Nigeria: Application of Garch and Var Models

\section{GARCH Estimation}

Volatility is arguably one of the most important concepts in (financial) econometrics and is measured by the standard deviation or variance of returns. It is a crude measure of the total risk of financial assets.

Oil price volatility is a measure that intends to capture the risk faced by the Nigerian economy due to unpredictable fluctuations in the price of crude oil. The study used a measure derived from Bollerslev (1986) generalized autoregressive conditional heteroskedasticity (GARCH) models using EViews.

As pointed out in Brooks (2014), before estimating a GARCH-type model, it is only sensible to first determine if this class of models is appropriate for the data. This verification of suitability is carried out by computing the Engle (1982) test for ARCH effects. The Engle test for the presence of ARCH in the residuals is calculated by regressing the squared residuals on a constant and $q$ lags, where $q$ is user specified. The first step involves estimating a linear model so that the residuals can be tested for ARCH. The next step is to run the Heteroskedasticity test (ARCH) using lag length of 5. Table 3 shows the Engle test results. Both the F-verion and the LM-statistics are very significant, suggesting the presence of ARCH in the oil price returns.

Table 3

Engel test for ARCH effects in the oil price data

\begin{tabular}{|l|r|r|r|r|}
\hline Heteroskedasticity Test: ARCH & & \\
\hline \hline F-statistic & 4.755024 & Prob. F(5,107) & 0.0006 \\
\hline Obs*R-squared & 20.54358 & Prob. Chi-Square(5) & 0.001 \\
\hline \hline Test Equation: & & & \\
\hline Dependent Variable: RESID^2 & & & \\
\hline Method: Least Squares & & & \\
\hline Date: 12/24/14 Time: $08: 26$ & & & \\
\hline Sample (adjusted): 1986Q3 2014Q3 & & \\
\hline Included observations: 113 after adjustments & \\
\hline \hline Variable & Coefficier Std. Error t-Statistic & Prob. \\
\hline \hline C & 33.99642 & 20.81932 & 1.632927 & 0.1054 \\
\hline RESID^2(-1) & 0.234481 & 0.096588 & 2.427651 & 0.0169 \\
\hline RESID^2(-2) & 0.347239 & 0.09899 & 3.507812 & 0.0007 \\
\hline RESID^2(-3) & -0.16672 & 0.103363 & -1.61296 & 0.1097 \\
\hline RESID^2(-4) & -0.03697 & 0.098987 & -0.373518 & 0.7095 \\
\hline RESID^2(-5) & 0.032155 & 0.096635 & 0.332751 & 0.74 \\
\hline \hline R-squared & 0.181802 & Mean dependent var & 57.49671 \\
\hline Adjusted R-squared & 0.143568 & S.D. dependent var & 219.1838 \\
\hline S.E. of regression & 202.8406 & Akaike info criterion & 13.51435 \\
\hline Sum squared resid & 4402443 & Schwarz criterion & 13.65917 \\
\hline Log likelihood & -757.561 & Hannan-Quinn criter. & 13.57312 \\
\hline F-statistic & 4.755024 & Durbin-Watson stat & 2.00112 \\
\hline Prob(F-statistic) & 0.000581 & & \\
\hline \hline & & & \\
\hline
\end{tabular}

Next, is to estimate a $\operatorname{GARCH}(1,1)$ model in EViews and the results are shown in table 4.

The coefficients on both the lagged squared residual and lagged conditional variance terms in the conditional variance equation are highly statistically significant. Similarly, as is to be expected of GARCH model estimates for financial asset returns data, the sum of the coefficients on the lagged square error and 


\section{Application of Garch and Var Models}

lagged conditional variance is very close to unity (approximately 0.94). The implication of this is that shocks to the conditional variance will be highly persistent.

Table 4

\section{GARCH estimation}

\begin{tabular}{|c|c|c|c|c|}
\hline \multicolumn{2}{|c|}{ Dependent Variable: OIL_PRICE } & & & \\
\hline \multicolumn{5}{|c|}{ Method: ML - ARCH (Marquardt) - Normal distribution } \\
\hline \multicolumn{2}{|c|}{ Date: $12 / 24 / 14$ Time: 08:33 } & & & \\
\hline \multicolumn{2}{|c|}{ Sample: 1985Q1 2014Q3 } & & & \\
\hline \multicolumn{2}{|c|}{ Included observations: 119} & & & \\
\hline \multicolumn{4}{|c|}{ Failure to improve Likelihood after 29 iterations } & \\
\hline \multicolumn{4}{|c|}{ Bollerslev-Wooldridge robust standard errors \& covariance } & \\
\hline \multicolumn{4}{|c|}{ Presample variance: backcast (parameter =0.7) } & \\
\hline \multicolumn{4}{|c|}{$\mathrm{GARCH}=\mathrm{C}(2)+\mathrm{C}(3)^{*} \mathrm{RESID}(-1)^{\wedge} 2+\mathrm{C}(4) * \mathrm{GARCH}(-1)$} & \\
\hline Variable & Coefficient & Std. Error & z-Statistic & Prob. \\
\hline \multirow[t]{2}{*}{$\mathrm{C}$} & 19.406490 & 0.249319 & 77.838000 & 0.000000 \\
\hline & \multicolumn{2}{|c|}{ Variance Equation } & & \\
\hline $\mathrm{C}$ & 31.996230 & 5.508865 & 5.808134 & 0.000000 \\
\hline $\operatorname{RESID}(-1)^{\wedge} 2$ & 1.099798 & 0.100591 & 10.933340 & 0.000000 \\
\hline GARCH(-1) & -0.162027 & 0.029964 & -5.407447 & 0.000000 \\
\hline R-squared & -0.474225 & \multicolumn{2}{|c|}{ Mean dependent var } & 43.336000 \\
\hline Adjusted R-squared & -0.474225 & \multicolumn{2}{|c|}{ S.D. dependent var } & 34.895870 \\
\hline S.E. of regression & 42.369750 & \multicolumn{2}{|c|}{ Akaike info criterion } & 7.913525 \\
\hline Sum squared resid & 211833.100000 & \multicolumn{2}{|c|}{ Schwarz criterion } & 8.006941 \\
\hline Log likelihood & -466.854700 & \multicolumn{2}{|c|}{ Hannan-Quinn criter. } & 7.951458 \\
\hline Durbin-Watson stat & 0.036875 & & & \\
\hline
\end{tabular}

The oil price volatility series is then generated by making the GARCH Variance Series in EViews and figure 3 gives the graph of this series.

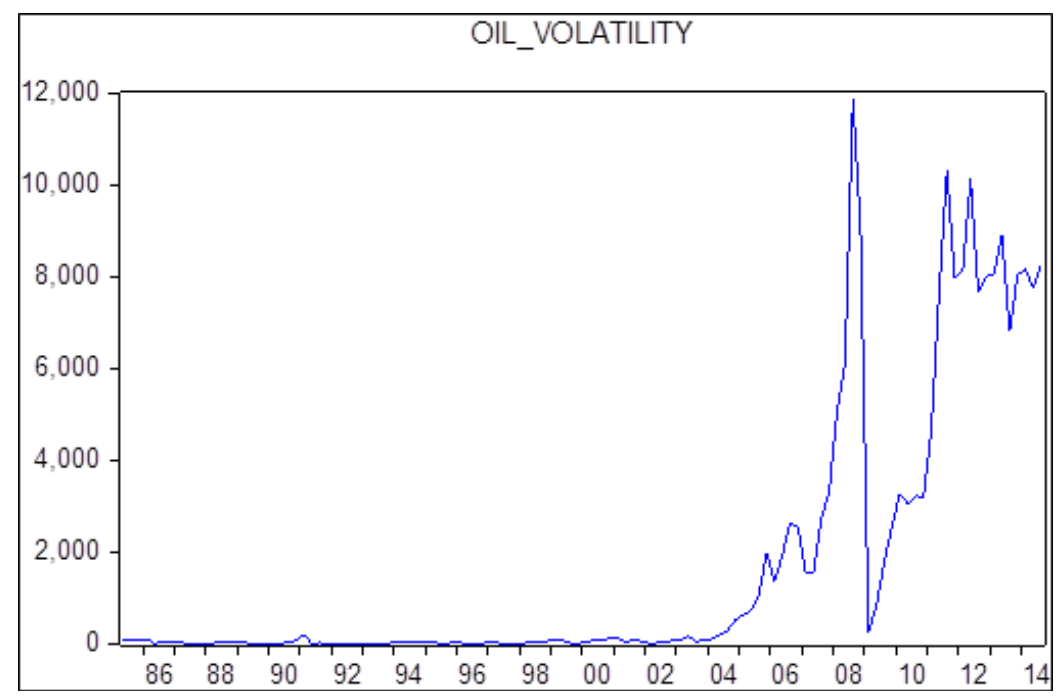

Figure 3. Oil price volatility. 
The Effects of Oil Price Volatility on Some Macroeconomic Variables in Nigeria: Application of Garch and Var Models

\section{VAR Estimation}

It is essential to determine the optimal lag length of the model, before estimating a VAR model. According to the results of Akaike Information Criteria (AIC) test, Likelihood Ratio (LR), Final Prediction Error (FPE), and Hannan-Quinn Information Criterion (HQ) optimal lag length of the VAR model was decided to be four for the model (See Table 5). The inverse roots of AR characteristic polynomials lie within the unit circle indicated that there was no problem in terms of stability of four-lag VAR model (See Figure 4).

Table 5

Lag selection criteria

\begin{tabular}{|r|r|r|r|r|r|r|}
\hline \multicolumn{1}{l|l}{ Lag } & \multicolumn{1}{l}{ LogL } & \multicolumn{1}{l}{ LR } & \multicolumn{1}{l|}{ AIC } & \multicolumn{1}{l|}{ SC } & \multicolumn{1}{l|}{ HQ } \\
\hline \hline 0 & -2233.654 & NA & $5.49 \mathrm{E}+12$ & 40.68462 & 40.78282 & 40.72445 \\
\hline 1 & -2125.487 & 206.5002 & $1.03 \mathrm{E}+12$ & 39.00886 & 39.49985 & 39.20801 \\
\hline 2 & -2092.707 & 60.19544 & $7.58 \mathrm{E}+11$ & 38.70377 & 39.58756 & 39.06224 \\
\hline 3 & -1977.308 & 203.5229 & $1.25 \mathrm{E}+11$ & 36.89651 & $38.17310^{*}$ & 37.4143 \\
\hline 4 & -1950.48 & $45.36382 *$ & $1.03 \mathrm{e}+11^{*}$ & $36.69963^{*}$ & 38.36902 & $37.37674 *$ \\
\hline 5 & -1939.894 & 17.12967 & $1.15 \mathrm{E}+11$ & 36.79807 & 38.86026 & 37.63451 \\
\hline 6 & -1934.394 & 8.499885 & $1.41 \mathrm{E}+11$ & 36.98898 & 39.44397 & 37.98474 \\
\hline 7 & -1929.53 & 7.16295 & $1.76 \mathrm{E}+11$ & 37.19146 & 40.03924 & 38.34654 \\
\hline 8 & -1913.526 & 22.40552 & $1.80 \mathrm{E}+11$ & 37.19139 & 40.43197 & 38.50578 \\
\hline \hline
\end{tabular}

* indicates lag order selected by the criterion

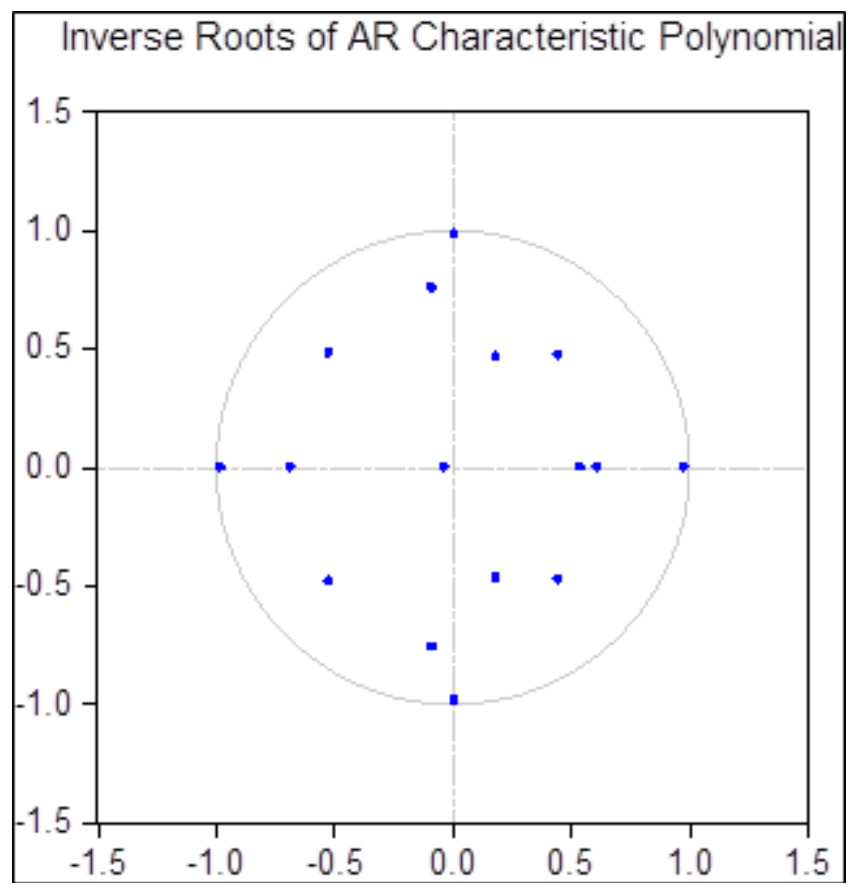

Figure 4. Inverse roots of AR characteristics polynomial for lag length 4

The VAR model which was generated according to this framework is shown as follows:

$$
x_{t}=m 2 r_{t} g d p r_{t} \operatorname{cspr}_{t} o p v_{t}
$$




\section{Results}

\section{Variance Decomposition}

Variance decomposition method is used to determine the source of the changes in the variable and to overcome the obstacles in the interpretation of the parameters in the VAR model (Cambazoglu and Karaalp, 2012).

Table 6

Cholesky variance decomposition of opv, cpsr, gdpr and $m 2 r$

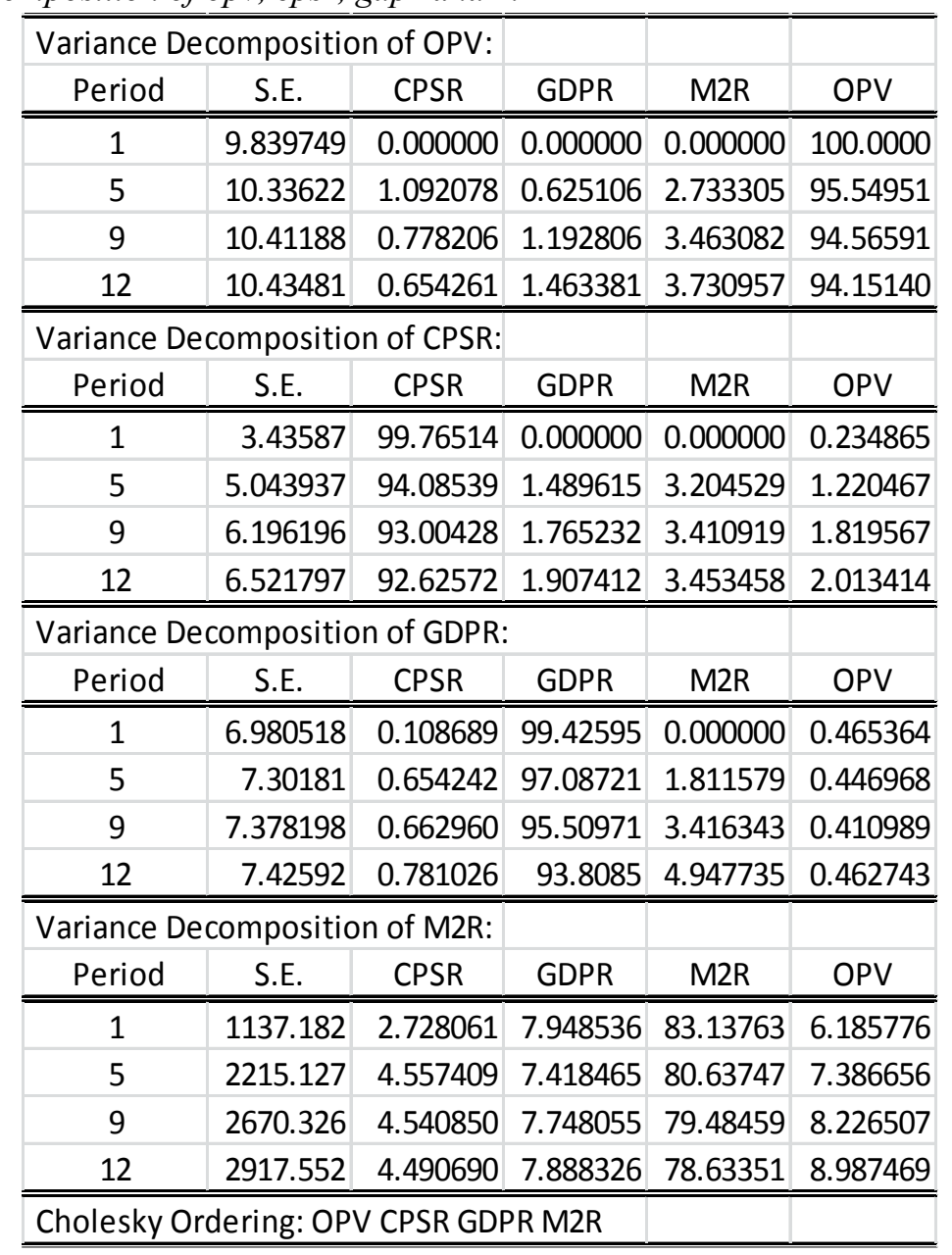

\section{Impulse-Response Analysis}

The response of variables to a shock or impulse from one of the other variables can be analyzed through impulse-response function. Therefore, the impulse-response function provides an avenue to estimate other variables' responses to the shocks that may occur in the future. 
The Effects of Oil Price Volatility on Some Macroeconomic Variables in Nigeria:

Application of Garch and Var Models

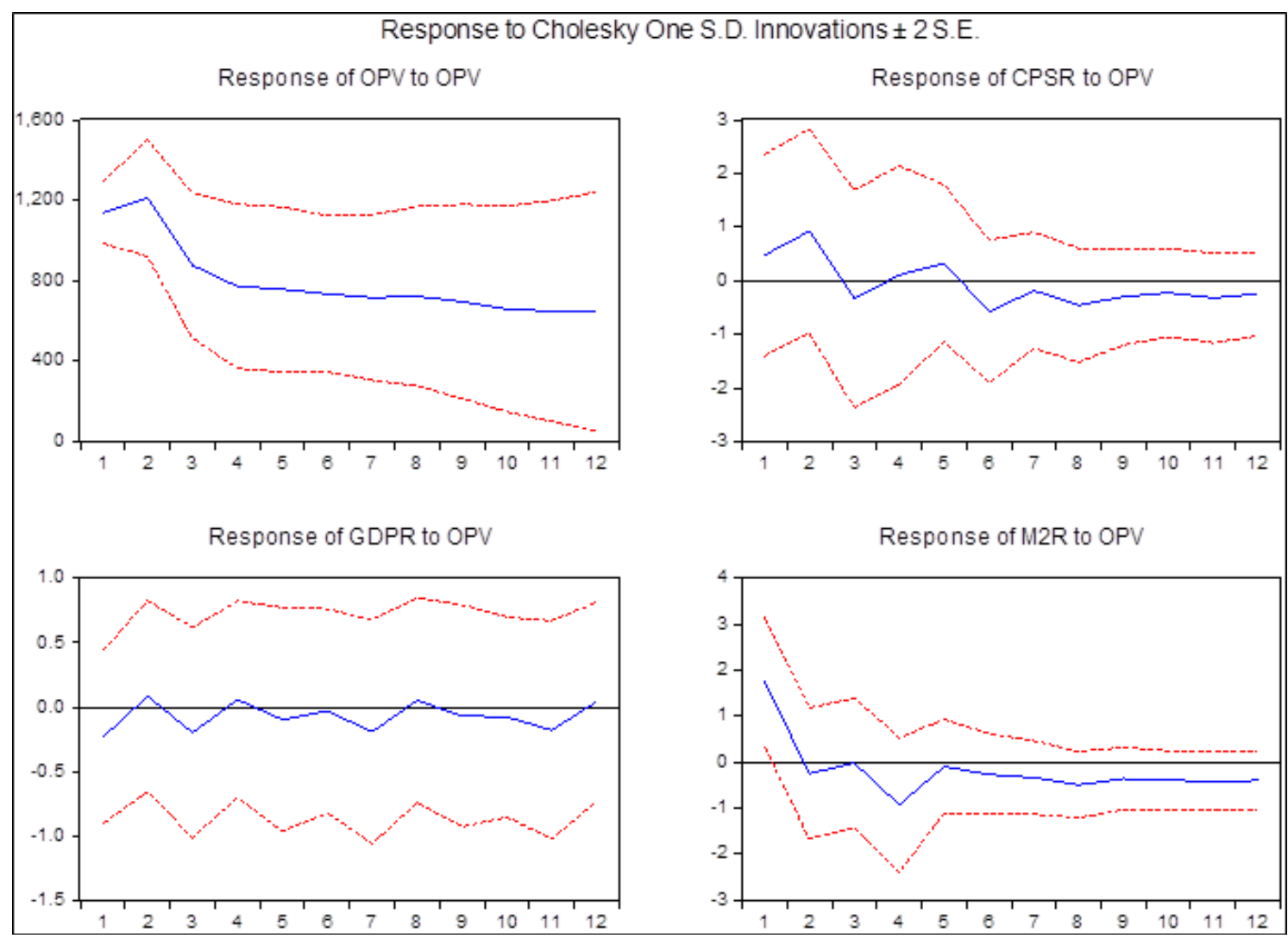

Figure 5. Response of cpsr, gdpr and m2r variables to shock from 'opv' variable

\section{Discussion}

According to the results of variance decomposition for twelve periods, the main source of variances of all variables is their own shocks. In this context, for twelve periods, the secondary basic source of the changes in the credit to private sector and GDP, is the ' $\mathrm{m} 2 \mathrm{r}$ ' variable with a share of 3.45 per cent and 4.94 per cent respectively. It is also found that 'opv' variable is the secondary source of the changes in the monetary assets with a share of 8.98 per cent.

The responses of other variables to one standard deviation of 'opv' variable shock obtained for twelve periods are shown in Figure 5. Horizontal axis indicates the yearly period of time after the shocks are given and the vertical axis indicates the response of variables to the shocks proportionately. Confidence intervals are provided by using Monte Carlo simulation for the impulse-response functions.

From Figure 5, it can be observed that the response of the 'opv' variable to its own shock was upwards between the beginning period and the second period and downward between the second period and the twelfth period. The response of 'cpsr' variable to the oil price volatility shock fluctuated from the first period up to the twelfth period. The response of 'gdpr' variable to the oil price volatility shock was found to also fluctuate from the first period up to the twelfth period. The response of ' $\mathrm{m} 2 \mathrm{r}$ ' variable was found to be downward from the beginning period to the second period. It then fluctuates between the second period and ninth period after which it disappears

In light of the empirical findings from Figure 5 for the inspected periods, the immediate and prolonged response of all the variables to the 'opv' shock indicates that these variables are all sensitive to changes 
(volatility) in oil price.

In this study, we have considered the speed and quality of three macroeconomic variables' responses to shocks in oil price. Without exception it was discovered that the impact of oil price shock on all three variables was immediate and prolonged. These responses show that credit to private sector, real GDP and total monetary assets variables are sensitive to the oil price variable. Therefore, the results of empirical findings indicate that the current intense volatility in the oil price will indeed have a negative impact on the economy because with a shortfall in credit to private sector, M2 and output will fall which will lead to unemployment and fall in non-oil revenue accruable to government.

This result agrees with Gunu and Abdulhakeem (2010) who discovered that oil prices had a significant impact on real GDP, money supply and unemployment but it contradicts Ogundipe and Ogundipe (2008) who concluded that oil price shocks do not have a direct impact on Real GDP, but rather oil price can influence other variables that significantly influence Real GDP like investment and savings. The results also disagrees with Mordi and Adebiyi (2010) who concluded that oil price changes play a significant role in determining the variance decompositions of output and prices as M2 was discovered to be the one that played a significant role in determining the variance decompositions of output.

Oil price shocks have a direct impact on real GDP, total monetary assets and credit to private sector and as such urgent and serious efforts should be made diversify the economy as well as improve the efficiency and scope of existing non-oil revenue sources, so as to ameliorate the impact of falling oil prices

\section{References}

Asaolu, T. O. and Ilo, B. M., The Nigerian Stock Market and Oil Price: A Cointegration Analysis, Kuwait Chapter of Arabian Journal of Business and Management Review, Vol. 1, No.5; 28-36. January 2012. Accessed on 02/02/2015

Bollershev, T. (1986) Generalised Autoregressive Conditional Heteroskedasticity, Journal of Econometrics 31, 307-27

Brook, C. (2014) Introductory Econometrics for Finance $3^{\text {rd }}$ Edition, Cambridge University Press.

Cambazoglu, B. and Karaalp, H. S. (2012) The Effects of Monetary Policy Shock of Employment and Output: The Case of Turkey. http://ijes.info/2/1/42542102.pdf. Accessed on July 23, 2014)

Campbell, J. (2014) Can Nigeria Endure Falling Oil Prices?, Council on Foreign Relations. http://www.cfr.org/nigeria/can-nigeria-endure-falling-oil-prices/p33967. Accessed on 02/02/2015

Engle, R. F. (1982) Autoregressive Conditional Heteroskedasticity with Estimates of the Variance of the United Kingdom Inflation, Econometrica 50(4), 987-1007

Umar, G. and Abdulhakeem, K. A. Oil Price Shocks and the Nigeria Economy: A Variance Autoregressive (VAR) Model, International Journal of Business Management, Vol. 5, No. 8; 39-49. August 2010. Accessed on 02/02/2015

Mordi, C. N. O. and Adebiyi, M. A. The Asymmetric Effects of Oil Price Shocks on Output and Prices in Nigeria using a Structural VAR Model, CBN Economic and Financial Review, Volume 48/1. 1-31. March 2010. Accessed on 02/02/2015

Petters, S. W. (2000) The Petroleum Sector, Online Nigeria (http://www.onlinenigeria.com/links/petradv.asp?blurb=484). Accessed on 02/02/2015

Odularu, G. O., (2008) Crude Oil and the Nigerian Economic Performance, Oil and Gas Business, Issue Number 1. p. 4. Accessed on $02 / 02 / 2015$

Ogundipe, O. and Ogundipe A., Impact of Oil Price Shocks on Investment in Nigeria. 2008 (Unpublished) Accessed on $01 / 12 / 2014$

Taylor, S. J. (1986) Forecasting the Volatility of Currency Exchange Rates, International Journal of Forecasting 3, 159-170 